ISSN 1023-6104

(c) Rajshahi University Zoological Society

\title{
Effect of the traditional parched rice husk incubation techniques on the hatchability of duck eggs
}

\author{
M. Khalequzzaman*, Shah Hussain Ahmad Mahdi and M. Mahbur Rahman \\ Department of Zoology, University of Rajshahi, Rajshahi 6205, Bangladesh \\ *Corresponding author, email: kzaman@ru.ac.bd
}

\begin{abstract}
The present study was carried out to know the seasonal effect on the hatchability of duck eggs in five private poultry farms at Gaibandha, Bangladesh. Eggs were set in artificial hatching bamboo made cylinders from different number of ducklings. Present observation revealed that the hatchability of duck eggs is highest in March $(88.966 \pm 2.11)$ and in June it is lowest $(66.398 \pm 0.63)$. In June the highest unfertilized eggs $(25.532 \pm 1.22)$ have been recorded followed by March (4.822 \pm 0.68$)$, January (10.164 \pm 0.12$)$, April $(10.408 \pm 0.31)$ and May (13.250 \pm 1.37$)$. The loss eggs were recorded highest in January $(21.244 \pm 1.36)$ and the lowest in March (4.874 \pm 2.05$)$. Least-square analysis of variance showed that individual months had significant effects on the hatchability of duck eggs.
\end{abstract}

Key words: Duck egg, artificial incubation, hatching

\section{Introduction}

The duck population in Bangladesh is 35 million that are commonly tended for meat and egg. In nature they are reared under traditional system in rural areas (FAO, 1990). Ducks have several advantages over other poultry species, in particular their disease tolerance. In Asia, most duck production is closely associated with wetland rice farming, particularly in the humid and subtropics. An added advantage is that ducks normally lay most of their eggs within the three hours after sunrise (compared with five hours for chickens). This makes it possible for ducks to freely range in the rice fields by day, while being confined by night (Farrell, 1986).

Local ducks in Bangladesh are ubiquitous in the country and most smallholder farmers keep them under a subsistent level of management (Islam et al., 2003). Duck comprises about $10 \%$ of the total poultry population, occupying second place to chicken in the production of table eggs in the country. It is an important component of farming system and plays a significant role to 80 per cent rural people of Bangladesh. It provides cash income and creates employment opportunity for rural people, particularly for small and landless farmers (Khan et al., 1999). It appears that the ducks can be raised cheaper than broiler and if market is properly organized (Singh, 2001). The process of hatching, which, in the span of 28 days for duck eggs, changes a microscopic germ into a downy chick, capable of walking, eating and expressing its needs by its voice and actions seems nearly magical (Banerjee, 1991). Novice poultry producers usually become interested in artificial incubation of their own chicks. The success of this type of project depends on proper care and incubation of the hatching eggs so healthy, vigorous chicks are produced (Smith, 2000). The artificial parched rice husk incubation process is started in some parts of
Bangladesh. The incubation generally performed from January to June. No study so far been done their performance, particularly on the hatchability of duck eggs and as such the present study was carried out.

\section{Materials and Methods}

Study Area: The present study was carried out in six private duck farms at Gaibandha, Bangladesh, where traditionally huge duck eggs are incubated artificially. The farms were selected at random including small, medium and large ones. Those farms also supply ducklings to the farmers once a week. The farms used to hatch ducklings from January to June. From late July to December they remain closed because during that period the air temperature drops and not suitable for artificial hatching of the eggs.

Rearing: The birds were reared in intensive system. The birds were kept in floor and large spacious shed surrounded by wire mesh/bamboo made sheets. Open space and water area were provided. Birds were fed outside the houses and the feed was allotted at the rate of 130-160 gm per head twice a day. Cleaning and sanitary programmes were followed regularly. Ducks were vaccinated with duck plague vaccine. In breeding flock one male duck was provided for every five females. Flock wise eggs were collected and graded for hatching purposes. Good quality clean eggs were collected for hatching purposes avoiding cracked ones. The eggs were stored with the narrower end pointed downward.

Incubation: This rice-husk system was adopted on a large scale in Bangladesh after being introduced by poultry development projects in the 1980s. The system has evolved, and the cylindrical egg baskets are now set into larger bamboo frame setting boxes, with more insulating rice husk material placed between the cylinders and the walls of the enclosing setting boxes. 
The cylinder wall is about $10 \mathrm{~cm}$ from the setting box wall and $8 \mathrm{~cm}$ from the next cylinder. With this greater insulation, there is less heat loss, thus less need to provide supplementary heat from costly fuels.

Eggs (45-50) were packed in black cloth and kept within the preheated (by 100w electric bulb) for one hour. Thus each cylinder contained 450-500 eggs. For the first three days, reheated paddy rice husk is added three times a day at regular intervals. During days four to six, this may be reduced to twice a day. The object is to ensure that the eggs are kept at the temperature most suitable for embryo development. The spare basket is used to transfer eggs from an adjoining basket while adding freshly warmed rice or rice-husks. Thus the top layer of eggs becomes the bottom layer and the bottom layer ends up on top of the spare cylinder. The newly emptied basket is then ready to receive eggs from the third basket, and so the cycle continues.

The eggs were candled on days 5 and 13, both to identify infertile eggs and dead embryos and to assess the degree of embryo development; which is used as one of the guides in adjusting basket temperature. Placing the egg on the upper eyelid allows the egg temperature to be assessed. Eggs in the advanced stages of incubation produce a lot of heat, so on days 17 to 18 , the "old eggs" are transferred to hatching beds, where they are placed in a single layer for final development and hatching. The surface of the bed is covered with a thin layer of rice husks and then covered with a straw mat. The edges of the bed are lined with padding to protect the eggs. The covering for the developing eggs in the bed may be heavy or light cloth, depending on the degree of insulation required. The temperature in the hatching bed is maintained at 36 to $37^{\circ} \mathrm{C}$, slightly lower than that of the basket. The temperature can be adjusted by changing the thickness of the covering, varying the space between the eggs, and moving the eggs twice a day so that those on the perimeter change places with those at the centre. In very hot dry weather, the eggs are sprayed with a fine mist of water. They are kept in the bed until the chicks hatch out and dry.

\section{Results and Discussion}

Month wise hatchability of duck eggs has been presented in Table 1. Highest hatchability was found in March $(88.966 \pm 2.11)$ and the lowest in June $(66.398$ $\pm 0.63)$. The least-square analysis of variance showed that the effect of month was highly significant $(\mathrm{P}<0.01)$ on the hatchability of duck eggs. Percent of infertile eggs and standard error has been presented in Table 2. In June the highest number of unfertilized eggs were observed $(25.532 \pm 1.22)$ followed by March $(4.822 \pm$ $0.68)$, January (10.164 \pm 0.12$)$, April (10.408 \pm 0.31$)$ and May (13.250 \pm 1.37$)$. The least square analysis of variance represents that the season had highly significant effect $(\mathrm{P}<0.01)$ on the percentage of infertile duck eggs (Table 2). The loss eggs were recorded highest in January $(21.244 \pm 1.36)$ and the lowest was in March (4.874 \pm 2.05$)$. Here also the ANOVA results are significant which indicates that there are differences in loss eggs within months.

Table 1. Number of hatched, unfertilized and loss duck eggs during artificial incubation

\begin{tabular}{|c|c|c|c|c|c|}
\hline Farm & Months & $\begin{array}{l}\text { Hatched } \\
\text { eggs }\end{array}$ & $\begin{array}{c}\text { Unfertilized } \\
\text { eggs }\end{array}$ & $\begin{array}{l}\text { Loss } \\
\text { eggs }\end{array}$ & $\begin{array}{l}\text { Total } \\
\text { eggs }\end{array}$ \\
\hline \multirow{6}{*}{1} & January & 9891 & 1484 & 2625 & 14000 \\
\hline & February & 14056 & 808 & 1136 & 16000 \\
\hline & March & 12138 & 910 & 952 & 14000 \\
\hline & April & 12080 & 1760 & 2160 & 16000 \\
\hline & May & 9450 & 2324 & 2226 & 14000 \\
\hline & June & 10952 & 4640 & 408 & 16000 \\
\hline \multirow{6}{*}{2} & January & 100290 & 13870 & 25840 & 140000 \\
\hline & February & 154240 & 3280 & 10480 & 160000 \\
\hline & March & 133840 & 3360 & 2800 & 140000 \\
\hline & April & 128176 & 17616 & 14208 & 160000 \\
\hline & May & 107240 & 14070 & 18690 & 140000 \\
\hline & June & 107500 & 39850 & 12650 & 160000 \\
\hline \multirow{6}{*}{3} & January & 5481 & 855 & 2064 & 8400 \\
\hline & February & 8176 & 487 & 937 & 9600 \\
\hline & March & 7839 & 463 & 98 & 8400 \\
\hline & April & 7224 & 896 & 1480 & 9600 \\
\hline & May & 5928 & 1274 & 1198 & 8400 \\
\hline & June & 6240 & 2561 & 799 & 9600 \\
\hline \multirow{6}{*}{4} & January & 7350 & 1050 & 2100 & 10500 \\
\hline & February & 10856 & 536 & 608 & 12000 \\
\hline & March & 9667 & 525 & 308 & 10500 \\
\hline & April & 10080 & 1224 & 696 & 12000 \\
\hline & May & 7350 & 1042 & 2108 & 10500 \\
\hline & June & 7876 & 2580 & 1544 & 12000 \\
\hline \multirow{6}{*}{5} & January & 6412 & 994 & 2334 & 9800 \\
\hline & February & 9520 & 608 & 1072 & 11200 \\
\hline & March & 8160 & 460 & 1180 & 9800 \\
\hline & April & 8400 & 1176 & 1624 & 11200 \\
\hline & May & 6915 & 1422 & 1463 & 9800 \\
\hline & June & 7359 & 2866 & 975 & 11200 \\
\hline
\end{tabular}

Despite the good results obtained in artificial hatching of Muscovy duck eggs in the last $10-20$ years, 81.8 to $83.4 \%$ (Avanzi \& Mori, 1983); 75-85\% (Sauveur \& De Carville, 1990); 80\% (Pingel, 1992) of hatchability were recorded. Hodgetts \& Tullett (1991) pointed out that hatchability of artificially incubated duck eggs was comparatively low. Specialists in that area tried to define the reasons in the insufficiently precision of some technological elements of the incubation process. For instance, the insufficient attention paid to the necessity of destroying the cuticle of the eggshell in the second half of incubation (Serbul \& Tardatjian, 1986), the prolonged true hatching in artificial incubation of eggs (Harun et al., 2001; Nickolova, 
2003, 2004, 2005). The least but not last, the unsatisfactory hatchability of the eggs of that species was due to the insufficiently precise temperature regime in artificial hatching (Bagliacca et al., 2003 $a, b)$. The difficulties in maximal optimization of temperature in the incubation and hatchery were due to the high content of fats in the egg yolk of the Muscovy ducks, that led to the increased release of heat in the second half of incubation (Nickolova et al., 1999).

Due to the above-mentioned reason, striving at bigger precision, a part of the researchers recommended different temperatures in the incubator depending on the period of embryonic development. For example, Serbul (1983) and Serbul \& Tardatjian (1986) recommended a temperature of $37.8-38.0^{\circ} \mathrm{C}$ until allantois closure (13-16 day of incubation), 37.5$37.4^{\circ} \mathrm{C}$ after allantois closure (16-30 day of incubation) and $37.5-37.4^{\circ} \mathrm{C}$ in the hatchery $(31-35$ day of incubation). Korotkova (1985) suggested that during the first three days the temperature should be maintained at $38.0^{\circ} \mathrm{C}$, until the $7^{\text {th }}$ day $37.8^{\circ} \mathrm{C}$, until allantois closure $37.6^{\circ} \mathrm{C}$ and in the hatchery $36.8-37^{\circ} \mathrm{C}$. The rest of the researchers in that area support the idea of one and the same temperature until the transfer of the eggs for hatching: Kortlang (1985) applied $37.3^{\circ} \mathrm{C}$ in the incubator and $36.9^{\circ} \mathrm{C}$ in the hatchery, Meltzer (1988) studied $37.5 \pm 0.2^{\circ} \mathrm{C}$ in the incubator, while Sauveur \& De Carville (1990) maintained a temperature of $37.6^{\circ} \mathrm{C}$ in the incubation cage and $37.2^{\circ} \mathrm{C}$ in the hatchery, whereas Bagliacca et al. (1991) applied $37.8 \pm 0.2^{\circ} \mathrm{C}$ and $37.2^{\circ} \mathrm{C} \pm 0.3^{\circ} \mathrm{C}$, respectively.

Table 2. Percent of hatched, unfertilized and loss duck eggs in different months

\begin{tabular}{lccc}
\hline \multicolumn{1}{c}{ Months } & $\begin{array}{c}\text { Hatchability } \\
(\%)\end{array}$ & $\begin{array}{c}\text { Unfertilized eggs } \\
(\%)\end{array}$ & Loss eggs (\%) \\
\hline January & $68.59 \pm 1.35$ & $10.16 \pm 0.12$ & $21.24 \pm 1.36$ \\
February & $88.97 \pm 2.11$ & $4.42 \pm 0.61$ & $7.79 \pm 0.79$ \\
March & $90.21 \pm 2.25$ & $4.82 \pm 0.68$ & $4.87 \pm 2.05$ \\
April & $77.97 \pm 1.78$ & $10.41 \pm 0.31$ & $11.62 \pm 1.84$ \\
May & $71.05 \pm 1.50$ & $13.25 \pm 1.37$ & $15.70 \pm 1.17$ \\
June & $66.40 \pm 0.63$ & $25.53 \pm 1.22$ & $8.07 \pm 1.64$ \\
\hline ANOVA & $37.57 * * *$ & $82.52^{* * *}$ & $15.49^{* * *}$ \\
(F-ratio) & & & \\
$* * *=\mathrm{P}<0.001$ & & & \\
\hline
\end{tabular}

In the present investigation it was recorded that the best hatching was observed during March. Similar results were found by Banerjee (1992) who reported that the best time to hatch chicks altogether depends upon the climate. Farooq et al. (2003) observed that the hatchability of chicken eggs was higher in spring

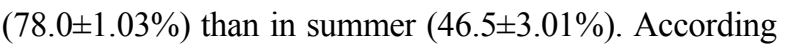
to Sastry et al. (1996) temperature was the most critical factor for incubation and the temperature affected both quantity and quality of hatching. Species of birds vary in their temperature requirements for incubation. Some wild species incubate and hatch their eggs at 29.4 to 32.2 C. For example, Ruddy duck eggs hatch with little or no external heat except for a few days of initial incubation at higher temperature. High incubation temperature results in embryonic mortality, particularly when there was high temperature during the last part of incubation period. Sastry et al. (1996) also reported that high humidity during incubation prevents sufficient evaporation from the eggs as a result of which large and soggy chicks were produced. High humidity also had a tendency to delay hatch and reduce hatchability. As subnormal incubation temperature causes late hatching and poor hatchability (Sastry et al., 1996). The fertility and rate of hatchability of eggs produced in summer and early spring was low (Das \& Ali, 1999; Chowdhury et al., 2004).

The effect of season on hatchability of duck eggs implies that March was the best for hatching of duck eggs, because of low rainfall and suitable room temperature. In conclusion, since the seasonal effect on hatchability is prominent, effort should be taken for more duckling production at that particular season to meet the increasing demand of ducklings in the region.

\section{References}

Avanzi C.F. \& Mori, B. 1983. Influenza dei fattori climatici sulla fertilita e sulla schusa dell' anatra muschiata, Avicoltura, 2: 27.

Bagliacca, M., Paci, G., Marzoni, M. \& Avanzi, C.F. 1991. Tecnologia di incubazione delle uova degli anatidi Incubation technology of duck egg. III Convegno CNR Gruppo Allevamenti delle piccole Specie, Roma. Edizioni Fondazione Iniziative Zoprofilattiche $e$ Zotecniche, 31: 95 -107.

Bagliacca, M., Paci, G. \& Marzoni, M. 2003a. Effect of egg weight categories, storage time and storage temperature on incubation length in Muscovy duck eggs (Cairina moschata L.) $2^{\text {nd }}$ World Waterfowl Conference, Alexandria Egypt (Oct 7 - 9).

Bagliacca, M., Marzoni, M. \& Paci, G. 2003b.Effect of egg weight categories, storage time and storage temperature on incubation length in Pekin duck eggs (Anas platyrhynchos L.). Avian poult. Biol. Rev. 14 (4): 195-196.

Banerjee, G.C. 1991. A Text Book of Animal Husbandry $7^{\text {th }}$ Edition, Oxford and IBH Publishing Co. Pvt. Ltd. New Delhi- Bombay-Calcutta, 747 pp.

Banerjee, G.C. 1992. Poultry. $3^{\text {rd }}$ Edition, Oxford and IBH Publishing Co. Pvt. Ltd., New Delhi, Calcutta, 57 pp. 
Chowdhury, M.M.I., Ashraf, A., Mondal, S.P., Mondol, N.M.A.A.M. \& Hasan, M.M. 2004. Effect of season on the hatchability of duck eggs. Int. J. Poult. Sci. 3(6): 419-421.

Das, G. B. \& Ali, M.L. 1999. Raising layer chicken over fish ponds in integrated poultry-fish farming system in rural areas. Bangladesh J. Anim. Sci. 28: 121-128.

FAO, 1990. Statistics on livestock population. Asian Livestock, XV(II): 150.

Farooq, M., Javed, K, Durrani, F.R., Irfanullah, K. \& Chand, N. 2003. Hatching performance of backyard hens in Peshawar, Pakistan. Livestock Research for Rural Development, 15.

Farrell, D.J. 1986. Energy expenditure of laying ducks: confined and herded. In: Duck Production Science and World Practice (eds. D.J. Farrell and P. Stapleton), pp. 70-82. University of New England, Armidale, NSW.

Harun, M., Veeneklaas, R.J, Visser, G.H. \& Van Kampen, M. 2001. Artificial Incubation of Muscovy Duck Eggs: Why some Eggs Hatch and Others do not. Poult. Sci. 80: 219- 224.

Hodgetts, B. \& Tullett, S.G. 1991. Current hatchabilities in species of domestic importance and the scope for improvement, Avian-incubation. 139-144; Poultry Science Symposium No. 22.

Islam, M.N., Huque, Q.M.E., Salahuddin, M. \& Sarker, M.S.K. 2003. Potentiality of Native Genotypes of Ducks. World Poult. Sci. Assoc. Bang. Branch J., 3: 259.

Khan, M.K.I., Ali, A. \& Bhuiyan, A.K.F.H. 1999. Economic traits of Deshi males with Isa brown females under farm and rural conditions. Bang. J. Anim. Sci. 28: 9.

Kortlang, C.F. 1985. The Incubation of Duck Eggs, Proc. of Workshop at CIPANAS, Bogor, Indonesia, November 18- 22, 1985.

Kostova, Z. 1985. Study on the major reproductive factors of Benkovska White goose and possibilities for regulating them. Unpubl. PhD thesis, Higher Institute of Agriculture, Plovdiv.

Meltzer, A. 1988. Incubation of Muscovy Duck Eggs, Proc. of International Symposium on Waterfowl Production, the Satellite Conference for the XVIII World's Poultry Congress, Beijing, China, 11-18 September 1988.
Nickolova M., Guerzilov, V., Penkov, D. \& Hristova, T. 1999. Alimentary composition of Muscovy duck's eggs. $12^{\text {th }}$ European Symposium on Waterfowl, Adana, Turkey. pp. 159-163.

Nickolova, M. 2003. Study on some major reproduction factors of Muscovy ducks (Cairina moschata) with elements of the incubation technology. Unpubl. $\mathrm{PhD}$ thesis (in Bulgarian). $188 \mathrm{pp}$.

Nickolova, M. 2004. Study on nesting behavior of Muscovy ducks (Cairina moschata) in conventional and biological breeding, XXII World's Poultry Congress, Istanbul, Turkey, 8-13 June 2004.

Nickolova, M. 2005. Study on the temperature regime in incubation of Muscovy duck eggs I. Study on temperature regime in natural hatched Muscovy duck eggs. J. Central European Agric. 6 (2): 185-190

Pingel H. 1992. Reproduction of Duck and Geese, XIX World Poultry Congres, Amsterdam, 3: 292- 301.

Sastry, N. S. R.; Thomas, C. K. \& Singh, R. A. 1996. Livestock Production Management, $3^{\text {rd }}$ Ed., Kalyani Publishers, New Delhi-Ludhiana, India. 559 pp.

Sauveur, B. \& De Carville, H. 1990. Effect of day-length on early puberty in female Muscovy ducks, Control of fertility in domestic birds, Tours, France, 2-4 July, Colloques-de-l'INRA. 1990, 54: 197-203.

Serbul V. 1983. Characteristics of Muscovy duck egg incubation, Ptitsevodstvo 6: 17- 19

Serbul, V.P. \& Tardatjian, G.A. 1986. Improving Muscovy duck eggs incubation technique, $7^{\text {th }}$ Conference Europeenne d' Aviculture, Paris, 1986.

Singh, R.A. 2001. Poultry Production, $3^{\text {rd }}$ Edition, Kalyani Publishers, New Delhi-Ludhiana, India. 345 pp.

Smith, A.J. 1990. Poultry-Tropical Agriculturist Series. pp.179-184 CTA, Macmillan, London.

Smith, T.W. 2000. Care and Incubation of Hatching Eggs. A popular article. Department of Poultry Science, Mississippi State University, USA. 421 pp.

Revised manuscript received on 28 May 2007. 